\title{
PENGARUH KOMPETENSI DOSEN TERHADAP MOTIVASI BELAJAR MAHASISWA \\ (SURVEY PADA MAHASISWA ANGKATAN 2012 KELAS B PROGRAM STUDI PENDIDIKAN AKUNTANSI UPI).
}

\author{
Abstrak \\ Badria Muntashofi \\ Kurjono
}

\begin{abstract}
Penelitian ini berawal dari fenomena motivasi belajar mahasiswa angkatan 2012 yang berada pada kategori sedang di Program Studi Pendidikan Akuntansi UPI. Faktor yang mempengaruhi motivasi, salah satunya adalah kompetensi dosen. Tujuan dari penelitian untuk mengetahui pengaruh kompetensi dosen terhadap motivasi belajar mahasiswa di Program Studi Pendidikan Akuntansi UPI. Metode yang digunakan dalam penelitian ini adalah metode survey .Populasi dalam penelitian ini mahasiswa angkatan 2012. Adapun hasil dari penelitian bahwa kompetensi dosen berpengaruh sebesar $40 \%$ terhadap motivasi belajar mahasiswa.
\end{abstract}

\section{Kata kunci: Kompetensi dosen, motivasi belajar mahasiswa}

\section{Pendahuluan}

Pendidikan mempunyai

tujuan dalam membentuk manusia yang berkualitas sesuai dengan yang tercantum dalam Undangundang Sistem Pendidikan Nasional UU No. 20 Tahun 2003 (2003: 56) yang isinya sebagai berikut: "Pendidikan nasional bertujuan untuk mengembangkan potensi peserta didik agar menjadi manusia yang beriman dan bertaqwa kepada Tuhan Yang Maha Esa, berakhlak mulia, sehat, berilmu, cakap, kreatif, mandiri dan menjadi warga Negara yang demokratis serta bertanggung jawab".

Dalam mewujudkan fungsi dan tujuan pendidikan nasional, terdapat masalah terkait dengan rendahnya motivasi belajar yang ditunjukkan dari hasil laporan Badan Internasional PBB, United Nations Development Programme (UNDP) terkait negara-negara menurut peringkat Human Development Index (HDI). Negara Indonesia berada pada peringkat 111 dari 175 negara (Chumhienk:2011). Hal tersebut dapat terjadi dikarenakan rendahnya mutupendidikan. Mutu pendidikan dipengaruhi oleh lima dimensi, salah satunya dan yang menjadi faktor awal adalah karakteristik pembelajar, sehingga pada dimensi ini diperlukan motivasi belajar pada setiap peserta didik.

Sementara itu, motivasi belajar masih menjadi masalah dalam dunia pendidikan sebagaimana yang disampaikan oleh Tanveer et al (2012) :

Over the years, lack of motivation in the classrooms remains one of the most concerning issues for teachers. According to Raffini (1996), in education, there should be three things to consider which are motivation, motivation, and motivation. According to Theobald (2006) in the 21st century, it becomes complex task and one of the biggest challenges for the teachers to motivate the students.

Seiring dengan tujuan pembentukan manusia yang 
berkualitas tersebut, perguruan tinggi sebagai lembaga formal mempunyai tugas dan tanggungjawab untuk membawa jalannya proses pendidikan yang baik dan bermutu. Perguruan tinggi merupakan miniatur kehidupan masyarakat yang kompleks dan menjadi wahana bagi peserta didik untuk mengaplikasikan apa yang dipelajari. Oleh sebab itu proses perkuliahan harus ditangani dengan baik sehingga menghasilkan output yang berkualitas. Pendidikan yang berkualitas tergantung dari sebuah proses pembelajaran yang terjadi di dalamnya. Dimana semua komponen yang berhubungan dengan aktivitas tersebut memiliki kaitan yang erat sehingga dapat menciptakan output yang diinginkan sesuai dengan tujuan yang telah ditetapkan sebelumnya.

Berkaitan dengan aspek kendala dalam pembelajaran, penelitian ini mencoba mengamati permasalahan pada mahasiswa angkatan 2011. Dari hasil wawancara pada mahasiswa semester 6 selama proses perkuliahan, diketahui bahwa motivasi mahasiswa lagi dalam kondisi kurang karena mahasiswa sudah mulai merasa jenuh dan juga tingkat kesukaran materinya cukup sulit. Apalagi kebanyakan cara dosen menjelaskan menggunakan metode ceramah dan latihan. Mahasiswa merasa ngantuk dengan cara belajar menggunakan ceramah, apalagi kalau dosennya dalam menjelaskan mata kuliah tidak bisa dipahami, atau kelihatannya kurang menguasai materi. Hal tersebut membuat malas dalam belajar. Jika hal seperti ini terus berlanjut tanpa adanya penelitian, tentu akan memberikan dampak yang tidak baik dalam perkembangan mahasiswa selanjutya. Untuk itu proses perkuliahan harus memotivasi mahasiswa untuk semangat dalam pembelajaran. Motivasi memiliki peranan yang penting dalam proses belajar karena motivasi dapat berperan sebagai penguat belajar, dapat memperjelas tujuan belajar yang akan dicapai, penentu ragam kendali terhadap rangsangan belajar dan dapat menentukan ketekunan belajar.

Peran dosen sebagai tenaga pendidik memiliki peranan penting untuk mendongkrak motivasi belajar mahasiswa agar tercapainya keberhasilan program pembelajaran. Seorang dosen haruslah menjadi figur teladan, sehingga dapat menjadi contoh yang baik bagi mahasiswanya. Selain menjadi tenaga pengajar, seorang dosen juga harus mampu mendidik, mengarahkan, menjadi fasilitator, dan motivator mahasiswanya agar mampu maju dan berkembang sesuai dengan cita-cita mereka sendiri.

Dalam kaitannya dengan motivasi belajar mahasiswa, dosen merupakan salah satu motor penggerak yang dapat menimbulkan motivasi belajar pada mahasiswa. Menurut Mulyasa "untuk meningkatkan kualitas pembelajaran guru/dosen harus mampu membangkitkan motivasi belajar peserta didik sehingga dapat mencapai tujuan pembelajaran." Oleh karena itu, dosen dituntut untuk memiliki peran dalam meningkatkan pendidikan yang terencana dan berkala. Dalam menjalankan perannya dosen harus selalu melakukan perkembangan atas dirinya sendiri baik itu dari aspek kompetensi maupun keterampilannya. Adapun kompetensi yang harus dimiliki dan dikembangkan oleh guru atau dosen 
menurut UU No.14 Tahun 2005 terdiri atas kompetensi pedagogik, kompetensi kepribadian, kompetensi profesional, dan kompetensi sosial.

Dosen dapat membangkitkan motivasi belajar mahasiswa dengan menjadikan dirinya sebagai sosok yang inspiratif dan menciptakan iklim pembelajaran yang kondusif dalam kegiatan belajar. Hal ini senada dengan pendapat Naim (2011:171) bahwa, "perpaduan antara guru/dosen yang inspiratif dalam pembelajaran akan menjadi dimensi inspiratif semakin menemukan momentum untuk mengkristal dan membangun energi perubahan positif dalam diri setiap siswa/mahasiswa." Perubahan positif inilah yang akan menimbulkan motivasi belajar dalam diri mahasiswa.

\section{Rumusan Masalah}

Berdasarkan latar belakang yang telah dijelaskan, maka masalah mengenai penelitian ini dapat dirumuskan sebagai berikut :

1. Bagaimana gambaran kompetensi dosen di Program Studi Pendidikan Akuntansi UPI.

2. Bagaimana gambaran motivasi belajar mahasiswa di Program Studi Pendidikan Akuntansi UPI.

3. Bagaimana pengaruh kompetensi dosen terhadap motivasi belajar mahasiswa di Program Studi Pendidikan Akuntansi UPI.

\section{KAJIAN TEORI DAN KERANGKA BERPIKIR \\ Kompetensi Dosen}

Kompetensi guru dan dosen menurut UU No.14 Tahun 2005 tentang Guru dan Dosen pasal 1 ayat 10 adalah "seperangkat pengetahuan, keterampilan, dan perilaku yang harus dimiliki, dihayati, dan dikuasai oleh guru atau dosen dalam melaksanakan tugas keprofesionalan."Sedangkan

menurut Mulyasa (2012:26) adalah sebagai berikut :Kompetensi guru/dosen merupakan perpaduan antara kemampuan personal, keilmuan, teknologi, sosial, dan spiritual yang secara kaffah membentuk kompetensi standar profesi guru, yang mencakup penguasaan materi, pemahaman terhadap peserta didik, pembelajaran yang mendidik, pengembangan pribadi, dan profesionalisme. Menurut Usman (2011:14) kompetensi guru/dosen adalah "kemampuan seseorang guru/dosen dalam melaksanakan kewajiban-kewajiban secara bertanggung jawab dan layak." Sedangkan Uno berpendapat (2008:64) bahwa:

Maka berdasarkan pengertian di atas dapat disimpulkan bahwa kompetensi dosen adalah kemampuan dosen dalam melaksanakan kewajiban yang diembannya yang harus didukung oleh seperangkat pengetahuan, keterampilan, dan perilaku yang harus dimiliki. Dalam mengemban tugas utamanya yaitu mendidik dan mengajar, dosen juga harus memiliki kompetensi yang dapat menunjang proses pembelajaran. Adapun kompetensi yang harus dimiliki oleh dosen meliputi empat aspek yaitu kompetensi pedagogik, kompetensi kepribadian, kompetensi profesional, dan kompetensi sosial.

Kompetensi Pedagogik

Dalam Peraturan Pemerintah Nomor 19 Tahun 2005 tentang Standar Nasional Pendidikan, penjelasan Pasal 28 ayat (3) butir a disebutkan bahwa kompetensi pedagogik adalah

Kemampuan mengelola pembelajaran peserta didik 
yang meliputi pemahaman terhadap peserta didik, perancangan, dan pelaksanaan pembelajaran, evaluasi hasil belajar, dan pengembangan peserta didik untuk mengaktualisasikan berbagai potensi yang dimilikinya.

Dalam kompetensi pedagogik ini dosen dituntut untuk dapat menjadi seorang manager dalam kelas. Dimana ia akan merencanakan, melaksanakan, dan melakukan pengawasan bagi proses pembelajaran terhadap mahasiswa di dalam kelas. Hal ini sesuai dengan yang dinyatakan oleh Mulyasa (2012:78) bahwa "guru diharapkan membimbing dan mengarahkan pengembangan kurikulum dan pembelajaran secara efektif, serta melakukan pengawasan dalam pelaksanaannya."

Indikator Kompetensi Pedagogik \begin{tabular}{lr}
\multicolumn{1}{c}{ Menurut } & $\begin{array}{l}\text { E.Mulyasa } \\
\text { kompetensi } \\
\text { (2012:75) } \\
\text { pedagogik sekurang- } \\
\text { kurangnya meliputi hal-hal } \\
\text { sebagai berikut: }\end{array}$
\end{tabular}

1. Pemahaman wawasan atau landasan kependidikan

2. Pemahaman terhadap peserta didik

3. Pengembangan kurikulum/silabus

4. Perancangan pembelajaran

5. Pelaksanaan pembelajaran mendidik dan dialogis

6. Pemanfaatan teknologi pembelajaran

7. Evaluasi Hasil Belajar (EHB)
8. Pengembangan peserta didik untuk mengaktualisasikan berbagai potensi yang dimilikinya

Sedangkan indikator kompetensi pedagogik guru menurut Direktorat Ketenagakerjaan Dirjen DIKTI dan Direktorat Profesi Pendidik Ditjen PMTK Depdiknas dengan modifikasi (Kunandar, 2008:75) meliputi sebagai berikut:

1. Memahami peserta didik secara

2. Merancang pembelajaran termasuk memahami landasan pendidikan untuk kepentingan pembelajaran

3. Melaksanakan pembelajaran

4. Merancang dan melaksanakan evaluasi pembelajaran

5. Mengembangkan peserta didik untuk mengaktualisasi berbagai potensinya

\section{Kompetensi Kepribadian}

Dalam Peraturan Pemerintah Nomor 19 Tahun 2005 tentang Standar Nasional Pendidikan, penjelasan Pasal 28 ayat (3) butir b, disebutkan bahwa yang dimaksud dengan kompetensi kepribadian adalah "kemampuan kepribadian yang mantap, stabil, dewasa, arif, dan berwibawa, menjadi teladan bagi peserta didik, dan berakhlak mulia."

Terkadang dalam proses pembelajaran di dalam kelas muncul perilaku mahasiswa dan kondisi lingkungan yang dapat memancing emosi dosen. Oleh karena itu, dosen mesti memiliki sifat dewasa dan 
stabil. Hal ini bertujuan agar tidak terjadi pertengkaran di dalam proses pembelajaran. Hendaknya seorang dosen tetap berwibawa dalam kondisi dan suasana hati bagaimanapun. Yang terpenting dosen harus selalu fokus pada tujuan pembelajaran yang akan dan ingin dicapai. Hal ini sesuai dengan pernyataan Mulyasa (2012:117) bahwa "pribadi guru memiliki andil yang sangat besar terhadap keberhasilan pendidikan, khususnya kegiatan pembelajaran."

\section{Indikator Kompetensi Kepribadian}

Adapun standar

kompetensi kepribadian guru dan dosen berdasarkan Permendiknas Nomor 16 Tahun 2007 dalam (Barnawi \& Arifin, 2012) mencakup lima hal sebagai berikut :

1. Bertindak sesuai dengan norma agama, hukum, sosial, dan kebudayaan nasional Indonesia.

2. Menampilkan diri sebagai pribadi yang jujur, berakhlak mulia, dan teladan bagi peserta didik dan masyarakat.

3. Menampilkan diri sebagai pribadi yang mantap, stabil, dewasa, arif, dan berwibawa.

4. Menunjukkan etos kerja dan tanggung jawab yang tinggi, rasa bangga menjadi guru, dan rasa percaya diri.

5. Menjungjung tinggi kode etik profesi guru

Sedangkan indikator kompetensi kepribadian guru menurut Direktorat Ketenagakerjaan Dirjen DIKTI dan Direktorat Profesi Pendidik Ditjen PMTK Depdiknas dengan modifikasi (Kunandar, 2008:75) adalah :

1. Kepribadian yang mantap dan stabil

2. Kepribadian yang dewasa

3. Kepribadian yang arif

4. Kepribadian yang berwibawa

\section{Kompetensi Profesional}

Dalam Peraturan Pemerintah Nomor 19 Tahun 2005 tentang Standar Nasional Pendidikan, penjelasan Pasal 28 ayat (3) butir $\mathrm{C}$ disebutkan bahwa yang dimaksud dengan kompetensi profesional adalah "kemampuan penguasaan materi pembelajaran secara luas dan mendalam yang memungkinkan membimbing peserta didik memenuhi standar kompetensi yang ditetapkan dalam Standar Nasional Pendidikan."

\section{Indikator Kompetensi Profesional} Menurut Mulyasa (2012:135), kompetensi profesional guru melingkupi :

1. Mengerti dan dapat menerapkan landasan kependidikan baik filosofi, psikologis, sosiologis, dan sebagainya;

2. Mengerti dan dapat menerapkan teori belajar sesuai taraf perkembangan peserta didik;

3. Mampu menangani dan mengembangkan bidang studi yang menjadi tanggungjawabnya;

4. Mengerti dan dapat menerapkan metode pembelajaran yang bervariasi; 
5. Mampu mengembangkan dan menggunakan berbagai alat media dan sumber belajar yang relevan;

6. Mampu mengorganisasikan dan melaksanakan program pembelajaran;

7. Mampu melaksanakan evaluasi hasil belajar peserta didik;

8. Mampu menumbuhkan kperibadian peserta didik.

\section{Kompetensi Sosial}

Dalam Peraturan Pemerintah Nomor 19 Tahun 2005 tentang Standar Nasional Pendidikan, penjelasan pasal 28 ayat (3) butir d disebutkan bahwa yang dimaksud dengan kompetensi sosial adalah "kemampuan guru/dosen sebagai bagian dari masyarakat untuk berkomunikasi dan bergaul secara efektif dengan peserta didik, sesama pendidik, tenaga kependidikan, orangtua/wali peserta didik, dan masyarakat sekitar." Sedangkan

Menurut Naim (2011:115) bahwa "tugas dan peran guru tidak hanya terbatas pada lingkungan sekolah saja, melainkan juga panutan masyarakat." Dengan adanya hubungan ini menciptakan keuntungan mutualisme diantara guru dan lingkungan yang disentuhnya.

\section{Indikator Kompetensi Sosial}

Menurut Mulyasa (2012:176) terdapat tujuh kompetensi sosial yang harus dimiliki oleh guru meliputi

1. Memiliki pengetahuan tentang adat istiadat baik sosial maupun agama;

2. Memiliki pengetahuan tentang budaya dan tradisi;
3. Memiliki pengetahuan tentang inti demokrasi;

4. Memiliki pengetahuan tentang estetika;

5. Memiliki apresiasi dan kesadaran sosial;

6. Memiliki sikap yang benar terhadap pengetahuan dan pekerjaan;

7. Setia terhadap harkat dan martabat manusia.

8. Hubungan Antar Kompetensi

\section{Pengertian Motivasi Belajar}

Para ahli mendefinisikan pengertian motivasi dengan cara dan gaya yang berbeda, namun esensinya menuju kepada maksud yang sama, seperti yang dikemukakan oleh Syamsudin (2005:37) bahwa motivasi itu merupakan :

(1)Suatu kekuatan (power) atau tenaga (forces) atau daya (energy), atau

(2)Suatu keadaan yang kompleks (a complex state) dan kesiapsediaan (preparatory set) dalam diri individu (organisme) untuk bergerak (to move, motion, motive) ke arah tujuan tertentu, baik disadari maupun tidak disadari.

Menurut Sadirman (2007:75) bahwa " Motivasi adalah serangkaian usaha untuk menyediakan kondisi-kondisi tertentu, sehingga seseorang mau dan ingin melakukan sesuatu, dan bila tidak suka, maka akan berusaha untuk meniadakan atau mengelakkan perasaan tidak suka itu ".

Menurut Uno (2010:3) bahwa “ Motivasi merupakan dorongan 
yang terdapat dalam diri seseorang untuk berusaha mengadakan perubahan tingkah laku yang lebih baik dalam memenuhi kebutuhannya ".

Motivasi dan Belajar merupakan dua hal yang saling mempengaruhi. Uno (2010:23) mengatakan bahwa " Motivasi belajar adalah dorongan internal dan eksternal pada siswa-siswa yang sedang belajar untuk mengadakan perubahan tingkah laku ".

Menurut Sadirman (2007:75) bahwa :

"Motivasi belajar merupakan faktor psikis yang bersifat nonintelektual. peranannya yang khas adalah dalam hal penumbuhan gairah, merasa senang dan semangat untuk belajar. siswa yang memiliki motivasi kuat, akan mempunyai banyak energi untuk melakukan kegiatan belajar"

Dalam proses belajar, motivasi sangat diperlukan. Semakin tinggi motivasi maka semakin bagus juga prestasi yang diperoleh, semakin rendah motivasi maka semakin rendah pula prestasi yang diperoleh, karena motivasi sebagai kekuatan, pendorong, untuk bergerak mencapai tujuan dan perubahan tingkah laku siswa dalam proses belajar. Jika seseorang memiliki motivasi yang kuat maka akan memiliki banyak energi untuk melakukan kegiatan belajar.

\section{Indikator Motivasi Belajar}

Indikator motivasi belajar menurut Uno (2010:23) dapat diklasifikasikan sebagai berikut

1. Adanya hasrat dan keinginan berhasil.
2. Adanya dorongan dan kebutuhan dalam belajar.

3. Adanya harapan dan citacita masa depan.

4. Adanya penghargaan dalam belajar.

5. Adanya kegiatan yang menarik dalam belajar.

6. Adanya lingkungan belajar yang kondusif, sehingga memungkinkan seseorang siswa dapat belajar dengan baik.

Beberapa cara pengukuran dan usaha peningkatan kekuatan motivasi kerja dan belajar menurut Syamsudin (2005:40) yang diidentifikasi dalam indikator sebagai berikut :

1. Durasinya kegiatan (berapa lama kemampuan penggunaan waktunya untuk melakukan kegiatan).

2. Frekuensinya kegiatan (berapa sering kegiatan dilakukan dalam periode waktu tertentu).

3. Persistensinya

(ketetapan dan kelekatannya) pada tujuan kegiatan.

4. Ketabahan, keuletan, dan kemampuannya dalam menghadapi rintangan dan kesulitan untuk mencapai tujuan.

5. Devosi (pengabdian) dan pengorbanan (uang, tenaga, pikiran, bahkan jiwanya atau nyawanya) untuk mencapai tujuan.

6. Tingkatan apirasinya (maksud, rencana, citacita, sasaran atau target, dan idolanya) yang 
hendak dicapai dengan kegiatan yang dilakukan.

7. Tingkatan kualifikasi prestasi atau produk atau output yang dicapai dari kegiatannya (berapa banyak, memadai atau tidak, memuaskan atau tidak).

8. Arah sikapnya terhadap sasaran kegiatan (like or dislike, positif atau negatif).

\section{Kerangka Pemikiran}

Peoses belajar mengajar merupakan kegiatan utama bagi seorang mahasiswa. Dari proses pembelajaran diharapkan terjadinya perubahan sikap, perluasan wawasan, serta tingkat pengetahuan dan keterampilan. Kualitas pendidikan bisa diukur dari tinggi rendahnya prestasi belajar. Namun untukmencapai prestasi belajar banyak sekali faktor yang mempengaruhiny. Salahsatu faktor yang mempengaruhi prestasi belajar mahasiswa adalah motivasi. Motivasi yang dimaksud disini adalah motivasi belajar. Dengan motivasi yag tinggi maka mahasiswa akan terdorong untuk selalu mempersiapkan diri dalam menghadapi proses belajar mengajar. Motivasi belajar mahasswa sangat diperlukan sebagai daya dorong. Namun motivasi belajar banyak faktor yang mempengaruhinya.

Motivasi dapat dibedakan menjadi dua macam, yaitu : 1) motivasi intrinsik, 2) motivasi ekstrinsik. Motivasi ekstrinsik yaitu motivasi yang membutuhkan rangsangan dari luar yang salah satunya yaitu dosen. Seorang dosen harus mampu memotivasi mahasiswanya untuk belajar. Doaen merupakan orang yang paling dekat dengan mahasiswa ketika di kampus. Mahasiswa akan termotivasi belajar di kelas jika dosen mampu membuat mahasiswa nyaman dan menyenangkan dalam proses pembelajaran.

Sebagai motivator, dosen hendaknya dapat mendorong mahasiswa agar bergairah dan aktif dalam belajar. Dengan demikian dosen mempunyai peranan yang penting dalam mengembangkan motivasi belajar mahasiswa. Untuk menunjang profesinya, dosen dituntut untuk memiliki kompetensi. Kompetensi dosen yang harus dimiliki mengacu pada undangundang guru dan dosen. Berdasarkan Peraturan Menteri Pendidikan Nasional Republik Indonesia Nomor 16 Tahun 2007 tentang Standar Kualifikasi Akademik dan Kompetensi Guru dan dosen. Dijelaskan bahwa Standar Kompetensi Guru dan dosen dikembangkan secara utuh dari empat kompetensi utama, yaitu: (1) kompetensi pedagogik, (2)kepribadian, (3) sosial, dan (4) profesional.

Dosen harus mampu menjadi agen perubahan sekaligus agen pembelajaran bagi mahasiswanya. Dengan bekal empat kompetensi ini, dosen dapat meningkatkan gairah serta motivasi belajar mahasiswa. Dosen dituntun untuk terus berupaya agar mahasiswa memiliki motivasi belajar dari dalam dirinya sendiri.Dengan menumbuhkan motivasi belajar pada mahasiswa, dosen ikut menentukan tingkat keberhasilan proses pembelajaran. Karena tanpa adanya motivasi maka tujuan pembelajaran yang dikehendaki akan sulit untuk dicapai secara optimal. Oleh karena itu, dosen dengan empat kompetensi yang dimilikinya bertanggung jawab untuk menciptakan iklim 
pembelajaran yang inspiratif sehingga dapat mempengaruhi dan membangkitkan motivasi belajar mahasiswa agar keberhasilan proses pembelajaran dapat tercapai maksimal.

Dalam proses pembelajaran di kelas dosen memegang peranan penting sebagai fasilitator dan motivator. Agar mahasiswa merasa termotivator oleh dosen maka dosen pun dituntut untuk selalu memiliki kompetensi yang dapat diandalkan. Kompetensi yang sudah ada lebih ditingkatkan karena dosen harus profesional. Dengan kompotensi dosen yang tinggi mahasiswa akan percaya dan pada akhirnya akan merasa termotivasi dalam belajar. Jadi semakin tinggi kompetensi dosen maka motivasi mahasiswa pun akan tinggi.

Berdasarkan kerangka pemikiran tersebut, maka dapat digambarkan hubungan penelitian variabel dalam penelitian yang dapat dilihat pada Gambar 2.1 berikut:

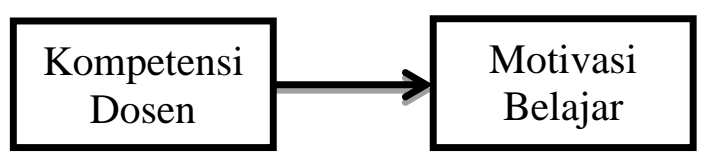

\section{Gambar 2.2 \\ Hubungan Variabel \\ Pengaruh Kompetensi Dosen \\ terhadap Motivasi Belajar Mahasiswa}

\section{Hipotesis}

Berdasarkan paradigma penelitian yang telah digambarkan, maka penulis merumuskan hipotesis bahwa "Kompetensi dosen berpengaruh positif terhadap motivasi belajar mahasiswa"

\section{METODE PENELITIAN Desain Penelitian}

Penelitian ini menggunakan tipe desain survei. Desain survei merupakan perancangan penelitian dengan tujuan melakukan pengujian yang cermat dan teliti terhadap suatu obyek penelitian (Subiyanto,2000:11). Adapun Metode yang digunakan pada penelitian ini adalah metode deskriptif verifikatif. Menurut Sugiyono (2010:11):

Penelitian deskriptif adalah penelitian yang dilakukan untuk mengetahui nilai variabel mandiri, baik satu variabel maupun lebih (independen) tanpa membuat perbandingan/ menghubungkan antara satu variabel dengan variabel yang lain, sedangkan metode verifikatif merupakan penelitian yang bertujuan untuk menguji kebenaran dari suatu hipotesis yang dilaksanakan melalui pengumpulan data di lapangan.

\section{Populasi dan Sampel}

Populasi dalam penelitian ini adalah seluruh Mahasiswa angkatan 2012 kelas B di Program studi Pandidikan Akuntansi UPI yang berjumlah 48 Mahasiswa.

\section{Instrumen Penelitian}

Data dalam penelitian ini dikumpulkan melalui angket atau kuesioner. Angket motivasi belajar mahasiswa disusun dalam skala numerik (numerical scale). Menurut Sekaran (2011 : 33) skala numerik mirip dengan skala diferensial semantik, dengan perbedaan dalam hal nomor pada skala 5 titik atau 7 titik disediakan, dengan kata sifat berkutub pada ujung keduanya.

\section{Teknik Pengumpulan Data}

Teknik pengumpulan data yang dilakukan dalam penelitian ini adalah dengan memberikan angket. Adapun angket yang akan 
digunakan dalam penelitian ini yaitu angket yang ada dalam penelitian Lia Anggraeni dengan sedikit perubahan yang tadinya ditujukan pada guru disini ditujukan pada dosen, karena angket tersebut sudah diuji reliabilitas dan validitas maka akan langsung digunakan sebagai angket untuk mengumpulkan data dalam penelitian ini.

\section{Pengujian Hipotesis (Uji t)}

Pengujian hipotesis diajukan untuk menentukan apakah hipotesis diterima atau ditolak dengan langkah-langkah pengujian sebagai berikut :

Menentukan hipotesis statistik

- $H_{0}: \rho=0$, Kompetensi dosen tidak berpengaruh terhadap motivasi belajar mahasiswa.

- $\mathrm{H}_{\mathrm{a}}: \rho \neq 0$, Kompetensi dosen berpengaruh terhadap motivasi belajar mahasiswa.

Menentukan $t$ hitung dengan menggunakan rumus sebagai berikut :

$$
\begin{aligned}
& \boldsymbol{t}_{\text {hitung }} \\
& =\frac{r \sqrt{n-2}}{\sqrt{1-r^{2}}}
\end{aligned}
$$

(Sudjana, 2004: 259)

Keterangan :

$\mathrm{t}=\mathrm{uji}$ signifikansi korelasi

$\mathrm{n}=$ jumlah sampel

$r=$ nilai koefisien korelasi

Kriteria :

- Jika nilai $t$ hitung $\geq$ nilai $t_{\text {tabel }}$ maka $\mathrm{H}_{0}$ ditolak dan menerima $\mathrm{H}_{\mathrm{a}}$.

- Jika nilai $t_{\text {hitung }} \leq$ nilai $t_{\text {tabel }}$ maka $\mathrm{H}_{0}$ diterima dan menolak $\mathrm{H}_{\mathrm{a}}$

\section{HASIL PENELITIAN DAN PEMBAHASAN}

Agar seorang dosen dapat menjalankan peran dan tugasnya dengan maksimal maka harus dibekali oleh kompetensi dan keterampilan yang menunjang. Kompetensi tersebut diantaranya adalah kompetensi pedagogik, kompetensi kepribadian, kompetensi profesional, dan kompetensi sosial. Keempat kompetensi tersebut memiliki kaitan yang erat sehingga dosen dapat menciptakan iklim pembelajaran yang inspiratif dan menyenangkan bagi mahasiswa. Hal ini tentunya dapat meningkatkan motivasi belajar mahasiswa sehingga dampaknya dapat terasa langsung pada keberhasilan pembelajaran dan tujuan pembelajaran yang dapat tercapai sesuai dengan yang telah ditetapkan.

Berdasarkan hasil perhitungan korelasi product moment didapar nilai $r$ sebesar 0,6345 , dari nilai $r$ tersebut untuk mengetahui besarnya pengaruh maka dicari dengan menggunakan rumus koefisien derminasi. Setelah dihitung dengan koefisien determinasi di dapat nilai $40 \%$, yang artinya motivasi belajar mahasiswa dipengaruhi oleh kompetensi dosen sebesar $40 \%$ dan sisanya dipengaruhi oleh faktor lain sebesar $60 \%$. Setelah di dapat besarnya pengaruh kompetensi dosen terhadap motivasi mahasiswa selanjutnya dilakukan uji hipotesis. Dari hasil uji hipotesis dengan menggunakan uji t maka didapat nilai $t$ hitung $(0,567813) \geq$ nilai $t$ table (1.67866) maka $\mathrm{H}_{0}$ ditolak dan menerima $\mathrm{H}_{\mathrm{a}}$, artinya terdapat pengaruh kompetensi dosen terhadap motivasi belajar mahasiswa. Hipotesis dalam penelitian ini diterima.

Berdasarkan hasil penelitian maka dapat diketahui bahwa 
kompetensi dosen merupakan satu kesatuan utuh yang tidak dapat dipisahkan yang tentunya harus dimiliki oleh seorang dosen. Jika dosen hanya memiliki salah satunya maka peran dan tugas yang diemban oleh dosen dalam aktivitas pembelajaran tidak akan tercapai secara maksimal. Hal ini akan menimbulkan ketimpangan bagi yang lainnya. Misalnya jika seorang dosen hanya memiliki dan unggul dalam kompetensi pedagogik saja tanpa ditunjang oleh kompetensi lainnya, maka akan mengalami kesulitan dalam melaksanakan aktivitas pembelajaran. Dosen hanya akan menonjol dalam mengelola pembelajaran namun mengalami ketimpangan dalam memiliki kepribadian yang dapat diteladani oleh mahasiswa, memiliki wawasan dan penguasaan materi secara mendalam, dan kemapuan dalam berinteraksi dan bersosialisasi dengan lingkungan di sekitarnya. Hal ini akan mempengaruhi proses pembelajaran yang terjadi di kelas.

Oleh karena itu, menjadi suatu hal yang penting bahwa dosen harus membekali dirinya dengan keempat kompetensi tersebut agar mencapai keseimbangan dalam menjalankan perannya sebagai pengajar sekaligus pendidik bagi mahasiswanya. Hal ini sesuai dengan yang dijelaskan oleh Mulyasa (141:2012) bahwa "guru yang tidak dibekali oleh kompetensi tersebut akan menghadapi berbagai kesulitan dalam membentuk kompetensi peserta didik, bahkan gagal dalam melaksanakan pembelajaran."

Dalam hal ini peran dosen sebagai tenaga pendidik memiliki peranan penting untuk mendongkrak motivasi belajar mahasiswa agar tercapainya keberhasilan program pembelajaran.
Kualitas seorang dosen merupakan salah satu komponen penting dalam dunia pendidikan. Hal tersebut karena kualitas seorang dosen akan menentukan dan memberi pengaruh besar terhadap kualitas pendidikan. Dosen haruslah menjadi figur teladan, sehingga dapat menjadi contoh yang baik bagi mahasiswanya. Selain menjadi tenaga pengajar, dosen juga harus mampu mendidik, mengarahkan, menjadi fasilitator, dan motivator mahasiswanya agar mampu maju dan berkembang sesuai dengan cita-cita mereka sendiri.

Dosen dapat membangkitkan motivasi belajar mahasiswa dengan menjadikan dirinya sebagai sosok yang inspiratif dan menciptakan iklim pembelajaran yang kondusif dalam kegiatan belajar. Oleh karena itu, Dosen dapat menjadi salah satu faktor yang memiliki peran penting dalam mengarahkan dan membangkitkan motivasi belajar mahasiswa agar dapat tumbuh dengan baik.

\section{Kesimpulan}

Berdasarkan hasil penelitian yang dilakukan, maka dapat ditarik beberapa kesimpulan sebagai berikut :

1. Kompetensi dosen yang meliputi kompetensi pedagogik berada dalam kategori sedang, kompetensi kepribadian berada dalam ketegori tinggi,. Kompetensi profesional berada dalam kategori sedangdan kompetensi sosial berada dalam kategori sedang.

2. Motivasi belajar mahasiswa Program studi pendidikan akuntansi UPI Bandung angkatan 2012 kelas B berada dalam kategori sedang. 
3. Kompetennsi dosen memiliki pengaruh pengaruh positif terhadap motivasi belajar mahasiswa sebesar $63 \%$.

\section{Saran}

Berdasarkan penelitian yang
telah dilakukan, penulis
menyampaikan beberapa saran
yang diharapkan dapat dijadikan
sebagai masukan yang bermanfaat
bagi semua pihak yang memerlukan.
Adapun saran yang peneliti
sampaikan adalah Dosen Program

\section{DAFTAR PUSTAKA}

Arikunto, S. (2007). Dasar-Dasar Evaluasi Pendidikan. Jakarta: Bumi Asara

Penelitian Suatu Pendekatan

Praktik. Jakarta: Rineka Cipta

Barnawi \& Arifin,M. (2012). Etika dan

Profesi Kependidikan. Yogyakarta:

Ar-Ruzz

Syah.M (2003). Psikologi Pendidikan

Suatu Pendekatan Baru.

Bandung: PT. Remaja

Rosdakarya

Hamalik.O.(2010). Proses Belajar

Mengajar. Jakarta: PT. Bumi Aksara . (2010). Kurikulum dan

Pembelajaran. Jakarta: Bumi

Aksara

Kunandar. (2008). Guru Professional Implementasi KTSP dan Sukses

Dalam Sertifikasi Guru. Jakarta: PT

Rajagrafindo Persada

Mulyasa, E. (2012). Standar Kompetensi dan Sertifikasi Guru.

Bandung: Rosdakarya

Purwanto, M.N. (2011). Psikologi Kependidikan. Bandung : PT. Remaja Rosdakarya.

Riduwan. (2010). Belajar Mudah Penelitian untuk Guru, Karyawan dan Peneliti Pemula. Bandung: Alfabeta

Syamsuddin, A M. (2005). Psikologi

Pendidikan. Bandung: Rosdakarya studi pendidikan akuntansi hendaknya senantiasa mempertahankan dan meningkatkan kompetensi yang dimilikinya meliputi kompetensi pedagogik, kompetensi kepribadian, kompetensi profesional, dan kompetensi sosial. Hal ini semata-mata agar dapat tercapainya tujuan pembelajaran yang akan berdampak langsung pada keberhasilan pendidikan.

Sardiman, A.M. (2007). Interaksi Motivasi dan Belajar Mengajar. Jakarta : PT. Raja Grafindo Persada

Sagala, S. (2009). Kemampuan Profesional Guru dan Tenaaga Kependidikan.

Bandung: Alfabeta

Sugiyono. (2010). Metode Penelitian Pendidikan. Bandung: Alfabeta Sekaran, U. (2011). Metodelogi Penelitian untuk Bisnis. Jakarta : Salemba Empat

Sudjana. (2004). Statistika untuk Ekonomi dan Niaga II. Bandung: Tarsito Uno, B.H. (2010). Teori Motivasi dan Pengukurannya. Jakarta : Bumi Aksara Usman, U . (2011). Menjadi Guru Profesional. Bandung: Remaja Rosdakarya. Naim, N. (2011). Menjadi Guru Inspiratif). Yogyakarta: Pustaka Belajar Santrock, J.W. (2007). Psikologi Pendidikan. Jakarta: Kencana 